\title{
Edaphic Macrofauna as Indicator of Edge Effect in Semi-deciduous Forest Fragments
}

\author{
Mariana dos Santos Nascimento ${ }^{1}$ (D), Patrícia Anjos Bittencourt Barreto-Garcia ${ }^{1}$ (D), \\ Rafael Nogueira Scoriza ${ }^{2}$ (D), Jhuly Ely Santos Pereira ${ }^{1}$
}

${ }^{1}$ Departamento de Engenharia Agrícola e Solos, Universidade Estadual do Sudoeste da Bahia - UESB, Vitória da Conquista/BA, Brasil

${ }^{2}$ Departamento de Agronomia, Universidade Federal Rural do Rio de Janeiro - UFRRJ, Seropédica - RJ, Brasil

\begin{abstract}
The aim of this study was to evaluate the edge effect using the macrofauna community of the soil as indicator in three fragments of Semi-deciduous Seasonal Forest in the city of Vitória da Conquista, Bahia, Brazil. Three sampling ranges denominated edge, transition and interior were delimited in each fragment. The macrofauna community was sampled at two seasons of the year (dry and wet). Monoliths were collected from soil at $10 \mathrm{~cm}$ depth in each range. The density and richness of the fauna, as well as the Shannon diversity index and the Pielou equitability index, were calculated. It was observed that the edge effect is expressed from the presence/absence of orders of individuals in the different fragment ranges, with no interference in the density, average wealth or number of individuals in each group. The edaphic community presents higher density and average richness in the dry period within the transition and interior range of the fragments.
\end{abstract}

Keywords: fragmentation, density, richness. 


\section{INTRODUCTION}

It is estimated that only $12.5 \%$ of the total original Atlantic Forest area is preserved in forest remnants. The situation in the state of Bahia is not different from the reality found in other regions of Brazil, currently presenting less than $12 \%$ of its original area (Brasil, 2015). The few remnants of deciduous forest are divided into fragments and are under strong influence of agropastoral activities with an emphasis on coffee growing areas, which include the cities of Vitória da Conquista, Jequié and Boa Nova, in Bahia state, Brazil (Batista et al., 2006).

Forest fragmentation promotes contact between a natural and anthropogenic habitat, causing profound changes in the ecosystem such as a loss of biodiversity and habitat alteration (Bierregaard et al., 1992; Brooks et al. 2002; Scariot et al., 2003). This is a consequence of the fact that many species avoid edge habitats, while others have their proliferation favored by less predation and/or increased resource availability (Wirth et al., 2008). This process is called the edge effect and generally consists of physical, chemical and biological changes in the ecosystem (Lima-Ribeiro, 2008). Its intensity is usually related to the fragment size, since its effects can reach more than 100 meters into the forest (Haskell, 2000), and the nature of the activities in the surrounding area (Abdo et al., 2015).

The changes resulting from this effect can be monitored by environmental indicators, which allow for quantifying and evaluating the conservation status of the forest fragments (Ferraz, 2011). This information can help understanding how ecosystemic processes and functions respond to the edge effect, which may mitigate forest restoration strategies (Riutta et al., 2016) and is of great interest to forest managers and conservationists.

Among the biological communities in soils, invertebrates can undergo changes in abundance, diversity, functional typology and distribution according to environmental conditions, modifying their ecological interactions and their role in ecosystem functionality (Bolger et al., 2000; Primack \& Rodrigues, 2001; Silva et al., 2007; Lindenmayer et al., 2008; Rantalainen et al., 2004; Riutta et al., 2012). Groups such as Formicidae, Coleoptera, Araneae, Diplopoda and Isoptera, which are representatives of the macrofauna, are fundamental to the ecosystem functioning because they occupy all the trophic levels in the soil food chain and affect the primary production in a direct and indirect way (Silva et al., 2006; Aquino et al., 2008). In addition, these groups promote organic waste fragmentation, nutrient cycling, soil aeration and nutrient mobilization (Lavelle et al., 1992).

Therefore, it is believed that the edge effect derived from forest fragmentation exerts a direct influence on the edaphic invertebrate community, thereby determining its size and diversity. Based on this assumption, the aim of this study was to evaluate the edge effect in three forest fragments of a transition region between Atlantic Forest and Caatinga using the macrofauna community of the soil as an indicator.

\section{MATERIALS AND METHODS}

\subsection{Study area}

The study was carried out in three fragments of semi-deciduous forest, regionally known as cipó forest, in the city of Vitória da Conquista, Bahia. The fragments have different sizes: Fragment 1 - smaller, with an

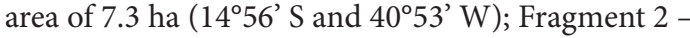
medium, with an area of 45 ha ( $14^{\circ} 52^{\prime} \mathrm{S}$ and $40^{\circ} 47^{\prime}$ W); and Fragment 3 - larger, with an area of 142 ha $\left(14^{\circ} 52^{\prime} \mathrm{S}\right.$ and $\left.40^{\circ} 41^{\prime} \mathrm{W}\right)$. They present similar forest structure and disturbance history, with pastures and agricultural crops predominating in their surroundings. They have different landscape conditions (Table 1): Fragments 1 and 2 are totally isolated from other forest remnants, while Fragment 3 is connected to two smaller fragments by a forest corridor (not evaluated in this study). The soils under the fragments belong to the same class: dystrophic Red and Yellow Latosol (Embrapa, 2006).

The region presents average annual temperature of $21^{\circ} \mathrm{C}$ and precipitation ranging between $700 \mathrm{~mm}$ and $1,100 \mathrm{~mm}$ per year. The period of greatest precipitation in the region occurs from November to March, with a dry period of four to five months (May to September) (Sousa et al., 2013). In addition, the territory is marked by great temporal and spatial variability in the rainfall distribution, characteristic of arid and semi-arid regions (Tagliaferre et al., 2012). The climate of the region is type Cwb according to the Köppen classification, which is a subtropical highland climate (Sousa et al., 2013). 
Table 1. Characterization of the forest fragments studied in relation to landscape.

\begin{tabular}{lccc} 
& & & Fragments $^{(1)}$ \\
\cline { 2 - 4 } \multicolumn{1}{c}{ Indexes } & $\mathbf{1}$ & $\mathbf{2}$ & $\mathbf{3}$ \\
Total area (ha) & 7.3 & 45 & 142 \\
Central area (ha) & 2.5 & 32 & 113 \\
Elevation (m) & 890 & 915 & 930 \\
ISO (m) & 683 & 661.5 & 342.5 \\
PROX (m) & 0.16 & 2.87 & 29.48 \\
\hline
\end{tabular}

${ }^{(1)} 1$ = smaller fragment (7.3 ha); 2 = medium fragment ( $\left.45 \mathrm{ha}\right) ; 3=$ larger fragment $(142 \mathrm{ha})$; Central area = fragment area excluding $50 \mathrm{~m}$ edges, calculated according to Murcia (1995); ISO = sum of the distance from each fragment to other forest fragments greater than 50 ha; PROX = proximity of forest fragments, obtained according to Vidal et al. (2007).

\subsection{Data collection}

Three evaluation ranges were identified in each of the fragments, named in this study as edge (from zero to 10 meters from the edge), transition (located at 40 to 50 meters from the edge), and interior (located in the center of the fragment, defined by half the distance between the ends of each fragment: 180,400, and $500 \mathrm{~m}$, respectively, for Fragments 1,2 and 3).

The soil macrofauna community was sampled in two seasons of the year (dry - September 2015, and wet - March 2016), using the method recommended by Tropical Soil Biology and Fertility program (Anderson \& Ingram, 1993). Five repetitions of a soil monolith with dimensions of $0.25 \mathrm{~m} \times 0.25 \mathrm{~m}$ and $10 \mathrm{~cm}$ depth were randomly collected in each range. It was ensured that the sampling points were at least $5 \mathrm{~m}$ equidistant. The soil monolith was placed on a plastic tray with a white background, and the organisms visible to the naked eye were collected. After that, the organisms were packed in plastic pots containing $70 \%$ alcohol. The invertebrates were then identified and counted in high taxonomic groups in the laboratory according to Dindal (1990).

Soil moisture (\%) was determined based on the difference between wet and dry mass (at $105^{\circ} \mathrm{C}$, for 48 hours), as three soil samples were also randomly collected per sampling range.

\subsection{Data analysis}

Density (number of individuals per $\mathrm{m}^{2}$ ), richness (number of groups identified) and Shannon diversity and Pielou equitability indexes were calculated based on the identification data of the soil macrofauna groups. The results were tested for homogeneity (Cochran and
Barttlet test, 5\%) and normality (Lilliefors test, 5\%). After checking the non-normality and homogeneity of the data, the non-parametric Kruskal-Wallis test was adopted at 5\% significance for comparisons between ranges at each season of the year (dry and wet) and the Wilcoxon test at $5 \%$ for comparison between seasons.

\section{RESULTS AND DISCUSSION}

In the three forest fragments studied, 15 groups of arthropods were sampled in the dry and wet seasons of the year. There were no significant differences in the density of invertebrate groups between the ranges and between the fragments in both periods (Tables 2 and 3 ).

There were also no differences between ranges in the number of individuals of each order and average richness (Figure 1). Thus, it was not possible to observe well-defined variation patterns for the Shannon diversity and Pielou equitability indexes (Tables 2 and 3).

These results show that there was no differentiation between the analyzed ranges for these parameters, meaning the edge, transition and interior. A distinct pattern was observed by Haskell (2000) who studied the effect of forest roads, reporting lower abundance and diversity of macroinvertebrates in the areas near the edges. The same author also reported that the edge effect reaches more than 100 meters into the forest on abundance, and reaches up to 15 meters on wealth (Haskell, 2000). According to Simpson et al. (2012), macrofauna feeding activity is also affected by fragmentation, decreasing with edge proximity.

The Isoptera order was the group that presented the highest number of individuals per $\mathrm{m}^{2}$ in both the dry and wet seasons, significantly influencing the total values observed (Tables 2 and 3). This result may be 
Table 2. Soil macrofauna community in the dry season in three sampled ranges of Seasonal Semi-deciduous Forest fragments in southwestern Bahia, Brazil.

\begin{tabular}{|c|c|c|c|c|c|c|c|c|c|}
\hline \multirow{2}{*}{ Groups } & \multicolumn{3}{|c|}{ Fragment $\mathbf{1}^{(\mathbf{1})}$} & \multicolumn{3}{|c|}{ Fragment 2} & \multicolumn{3}{|c|}{ Fragment 3} \\
\hline & Edge & Transition & Interior & Edge & Transition & Interior & Edge & Transition & Interior \\
\hline Araneae & 32.0 & - & - & - & $9.6 \mathrm{a}$ & $9.6 \mathrm{a}$ & - & $12.8 \mathrm{a}$ & $19.2 \mathrm{a}$ \\
\hline Blattodea & $12.8 \mathrm{a}$ & $6.4 \mathrm{a}$ & - & - & $19.2 \mathrm{a}$ & $12.8 \mathrm{a}$ & - & - & - \\
\hline Chilopoda & - & $12.8 \mathrm{a}$ & $19.2 \mathrm{a}$ & $3.2 \mathrm{a}$ & $19.2 \mathrm{a}$ & $19.2 \mathrm{a}$ & 6.4 & - & - \\
\hline Coleoptera & $6.4 \mathrm{a}$ & $6.4 \mathrm{a}$ & $12.8 \mathrm{a}$ & $3.2 \mathrm{a}$ & - & $9.6 \mathrm{a}$ & 12.8 & - & - \\
\hline Diplopoda & - & - & - & - & - & - & - & - & - \\
\hline Diptera & - & - & - & - & $3.2 \mathrm{a}$ & - & - & - & - \\
\hline Formicidae & - & $12.8 \mathrm{a}$ & $6.4 \mathrm{a}$ & $25.6 \mathrm{a}$ & $12.8 \mathrm{a}$ & - & - & $83.2 \mathrm{a}$ & $89.6 \mathrm{a}$ \\
\hline Gastropoda & $6.4 \mathrm{a}$ & - & - & - & $3.2 \mathrm{a}$ & $6.4 \mathrm{a}$ & - & $25.6 \mathrm{a}$ & $6.4 \mathrm{a}$ \\
\hline Hymenoptera & - & - & - & - & - & - & - & - & - \\
\hline Isoptera & $537.6 \mathrm{a}$ & $48.0 \mathrm{a}$ & $320.0 \mathrm{a}$ & $198.4 \mathrm{a}$ & $387.2 \mathrm{a}$ & $425.6 \mathrm{a}$ & $57.6 \mathrm{a}$ & $275.2 \mathrm{a}$ & $396.8 \mathrm{a}$ \\
\hline Coleoptera larvae & $12.8 \mathrm{a}$ & $6.4 \mathrm{a}$ & - & - & $3.2 \mathrm{a}$ & $22.4 \mathrm{a}$ & $16.0 \mathrm{a}$ & $25.6 \mathrm{a}$ & $38.4 \mathrm{a}$ \\
\hline Diptera larvae & $6.4 \mathrm{a}$ & $12.8 \mathrm{a}$ & - & $3.2 \mathrm{a}$ & $6.4 \mathrm{a}$ & $9.6 \mathrm{a}$ & $6.4 \mathrm{a}$ & $6.4 \mathrm{a}$ & - \\
\hline Lepidoptera larvae & $6.4 \mathrm{a}$ & - & - & $3.2 \mathrm{a}$ & - & - & - & $6.4 \mathrm{a}$ & - \\
\hline Pseudoscorpions & - & - & 6.4 & - & - & 3.2 & - & - & - \\
\hline Scorpionidae & - & - & - & $3.2 \mathrm{a}$ & - & - & - & - & - \\
\hline Total richness & 8 & 7 & 5 & 7 & 9 & 9 & 5 & 7 & 5 \\
\hline Shannon & 0.90 & 2.36 & 0.76 & 0.99 & 1.09 & 1.18 & 1.77 & 1.68 & 1.28 \\
\hline Pielou & 0.30 & 0.84 & 0.33 & 0.35 & 0.34 & 0.37 & 0.76 & 0.60 & 0.55 \\
\hline
\end{tabular}

(1) Fragment 1 = smaller fragment $(7.3 \mathrm{ha})$; Fragment 2 = medium fragment (45 ha); Fragment 3 = larger fragment (142 ha). Equivalent letters in the row comparing the sampling ranges by fragment do not differ from each other by the Kruskal-Wallis test at $5 \%$ significance.

Table 3. Soil macrofauna community in the wet season in three sampled fragment ranges of Seasonal Semi-deciduous Forest in southwestern Bahia, Brazil.

\begin{tabular}{|c|c|c|c|c|c|c|c|c|c|}
\hline \multirow{2}{*}{ Groups } & \multicolumn{3}{|c|}{ Fragment $\mathbf{1}^{(\mathbf{l})}$} & \multicolumn{3}{|c|}{ Fragment 2} & \multicolumn{3}{|c|}{ Fragment 3} \\
\hline & Edge & Transition & Interior & Edge & Transition & Interior & Edge & Transition & Interior \\
\hline Araneae & - & - & - & - & 6.4 & 3.2 & $6.4 \mathrm{a}$ & $3.2 \mathrm{a}$ & $9.6 \mathrm{a}$ \\
\hline Blattodea & 3.2 & - & - & - & 3.2 & 9.6 & 3.2 & - & 6.4 \\
\hline Chilopoda & - & 3.2 & 12.8 & 9.6 & 3.2 & - & - & 3.2 & 12.8 \\
\hline Coleoptera & 3.2 & - & - & 3.2 & - & - & - & - & 3.2 \\
\hline Diplopoda & - & - & - & $3.2 \mathrm{a}$ & $3.2 \mathrm{a}$ & $9.6 \mathrm{a}$ & $3.2 \mathrm{a}$ & $3.2 \mathrm{a}$ & $3.2 \mathrm{a}$ \\
\hline Diptera & - & - & - & - & - & - & - & - & - \\
\hline Formicidae & - & 3.2 & 6.4 & 16.0 & 12.8 & - & $9.6 \mathrm{a}$ & $16.0 \mathrm{a}$ & $9.6 \mathrm{a}$ \\
\hline Gastropoda & - & - & - & - & - & 3.2 & - & - & - \\
\hline Hymenoptera & - & - & - & - & 3.2 & - & - & - & - \\
\hline Isoptera & $262.4 \mathrm{a}$ & $118.4 \mathrm{a}$ & $524.8 \mathrm{a}$ & $140.8 \mathrm{a}$ & $80.0 \mathrm{a}$ & $118.4 \mathrm{a}$ & $208.0 \mathrm{a}$ & $12.8 \mathrm{a}$ & $224.0 \mathrm{a}$ \\
\hline Coleoptera larvae & - & 6.4 & 3.2 & 3.2 & 9.6 & - & - & 3.2 & 3.2 \\
\hline Diptera larvae & 6.4 & 3.2 & - & 12.8 & 3.2 & - & $3.2 \mathrm{a}$ & $6.4 \mathrm{a}$ & $3.2 \mathrm{a}$ \\
\hline Lepidoptera larvae & - & - & - & - & - & - & - & - & - \\
\hline Pseudoscorpions & - & - & - & 3.2 & - & - & - & - & - \\
\hline Scorpionidae & - & 3.2 & - & 3.2 & - & - & - & - & - \\
\hline Total richness & $4 \mathrm{a}$ & 6 & 4 & 9 & 9 & 5 & 6 & 7 & 9 \\
\hline Shannon & $0.34 \mathrm{a}$ & 0.90 & 0.30 & 1.59 & 1.93 & 1.00 & 0.73 & 2.47 & 1.21 \\
\hline Pielou & $0.17 \mathrm{a}$ & 0.35 & 0.15 & 0.50 & 0.61 & 0.43 & 0.28 & 0.88 & 0.38 \\
\hline
\end{tabular}

${ }^{(1)}$ Fragment 1 = smaller fragment $(7.3$ ha); Fragment 2 = medium fragment $(45 \mathrm{ha})$; Fragment 3 = larger fragment (142 ha). Equivalent letters in the row comparing the sampling ranges by fragment do not differ from each other by the Kruskal-Wallis test at $5 \%$ significance. 

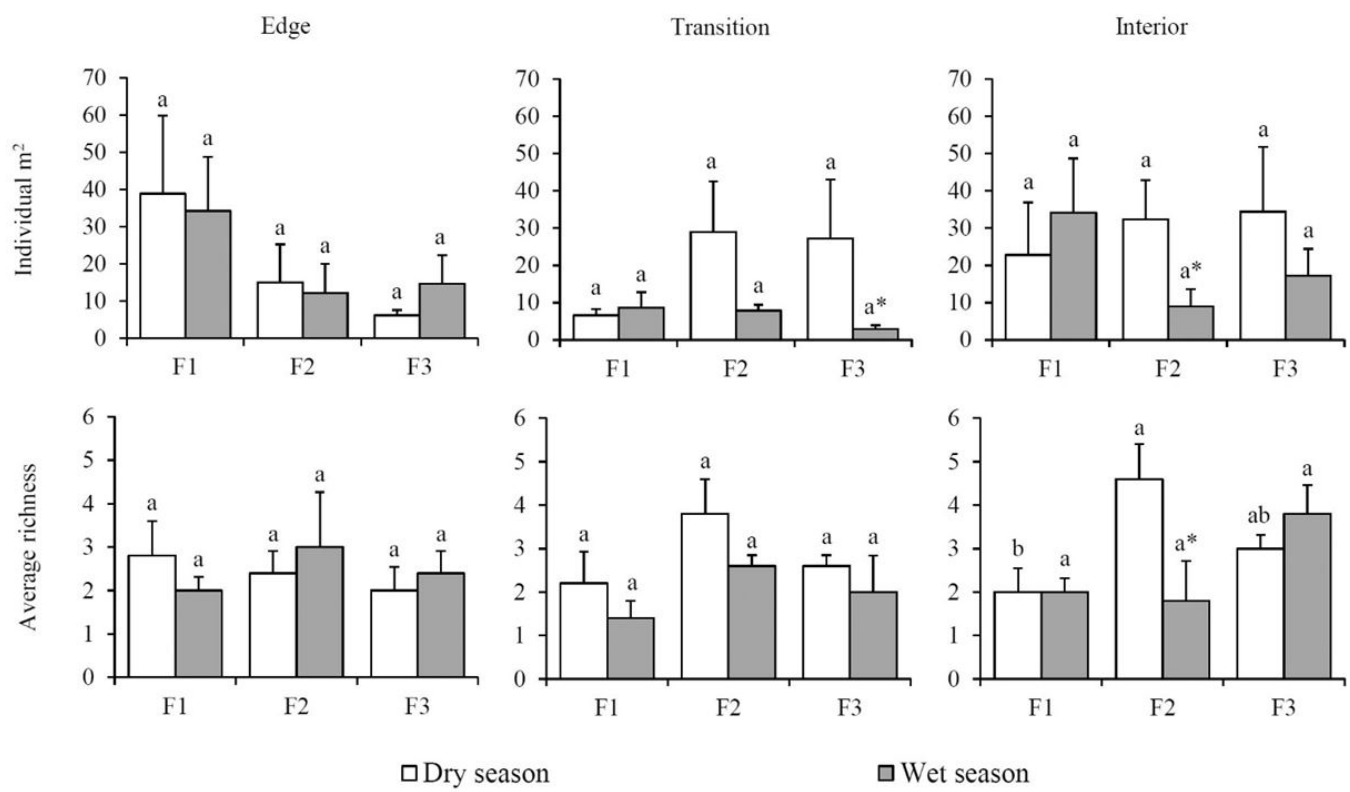

Figure 1. Total number of individuals and average wealth of the edaphic macrofauna community of three forest fragments in two periods of the year (dry and wet). F1 = smaller fragment ( $7.3 \mathrm{ha}) ; \mathrm{F} 2=$ medium fragment ( $45 \mathrm{ha}$ ); F3 = largest fragment (142 ha). Equal line letters comparing the fragments at each season do not differ by the Kruskal-Wallis test at $5 \%$ significance. ${ }^{*}$ indicates significant difference between seasons by the Wilcoxon test at $5 \%$.

related to the fact that termites have the ability to adapt to disturbances and remain active in severe environments or during dry seasons, when most arthropods decrease their activity, since they can maintain the humidity of their nests (Lavelle et al. al., 1996; Jouquet et al., 2011). Another factor to be considered is the occurrence of eucalyptus planted forests in the vicinity of the studied forest fragments, considering that most species of this order predominantly occur in exotic forests (Dorval et al., 2005).

When analyzing the presence/absence of the different orders in each of the ranges in the two evaluation periods, it was possible to observe that in the middle fragment (Fragment 2), the Formicidae group occurred only in the edge and transition ranges (Tables 2 and 3), meaning in the zone closest to the fragment exterior. Studies in tropical and subtropical forests have shown that the richness and abundance of this group is higher in environments near the edge (Pinheiro et al., 2010). This is usually related to a higher deposit of litter (mainly composed of leaves and branches) as a result of higher light and wind incidence (Murcia, 1995).

Still in the middle fragment, other orders like Blattodea and Gastropoda were only found in the transitional ranges and in the interior (Tables 2 and 3 ). The environmental characteristics of the zone closest to the edge may have been a limiting factor for the occurrence of these orders. The edge presents more severe conditions, greater exposure to solar radiation, rain and wind, which cause constant change in the ecosystem characteristics, such as in soil moisture. Normally species found in edge regions are adapted to situations of stress or limitations to survival (Ribeiro, 2011; Riutta et al., 2016).

Considering the greater end-center distance of the larger fragment, significant differences between the edaphic fauna of the edge and the interior would be expected. However, when analyzing the number of individuals from each group of the larger fragment, no significant variations were identified between these two environments in the two evaluation periods (Tables 2 and 3). This may be an indication that the edge effect did not interfere in the establishment of the macrofauna community in the soil in the larger fragment.

Similarly, no variations were detected between the ranges in the smaller fragment (Fragment 1) (Tables 2 and 3), which could suggest an absence of 
edge effect. However, it is likely that this result is related to the already expected influence of the smaller size and greater isolation of this fragment (Table 1), which would be causing a vulnerable condition throughout its length. According to Laurance \& Vasconcelos (2009), the ecological changes that occur due to isolation are generally proportional to the fragment size. Thus, the observed result would be explained by the dominance in proportion to edge habitats, which renders biotic and physical differences of the edge environment imperceptible in relation to the interior (González et al., 2015). Copatti \& Gasparetto (2013) and González et al. (2015) emphasize that reduced forest fragment sizes accompanied by great disturbance and environmental degradation results in impoverishing the herbivore, predator and parasitoid communities, reaching larger proportions in smaller fragments.

When analyzing the results obtained for the two seasons of the year, it was possible to observe that the Hymenoptera and Diplopoda groups only occurred in the wet season (Table 3). In the case of Diplops, this occurrence is explained by the fact that they are in a dormant state in the dry period of the year (Uhlig, 2005), since their activity depends on the availability of energy resources from the litter biomass during the wet season (Teixeira et al., 2014). In turn, the Diptera and Lepidoptera larvae only occurred in the dry season (Table 2). The other groups of macroinvertebrates were found in dry and wet seasons (Tables 2 and 3). This result may be related to the fact that the soil presented moisture content between $7 \%$ and $8 \%$ in the two seasons of the year without significant differences, since soil moisture is one of the factors that influences the activity of soil organisms (Simpson et al. Riutta et al., 2016). When comparing the ranges of each fragment between the seasons of the year, differences were observed both in the number of individuals per square meter $\left(\mathrm{m}^{2}\right)$ and in the average richness of the interior of the middle fragment, which presented higher values in the dry period (Figure 1). In the larger fragment, differences between seasons were only observed for the number of individuals in the transition ranges, which was also higher in the dry period (Figure 1). The higher average richness and density of the fauna in the dry season may be a reflection of the higher density of the Isoptera group, which (as previously discussed) usually remains active even under water restriction conditions (Lavelle, 1996; Jouquet et al., 2011). In addition, such results may be related to the larger litter deposition normally observed at the end of the dry season, as found by Vital et al. (2004) in Semi-deciduous Seasonal Forest (Figure 1).

A significant variation was observed in the average interior richness when comparing the ranges between the three fragments for each season of the year, which was lower in the smaller fragment in relation to the middle fragment (Figure 1). According to Laurance \& Vasconcelos (2009), small fragments generally not only contain a lower species richness as a whole, but also a lower density of species per unit area in many cases, when compared to larger fragments or to a continuous forest.

\section{CONCLUSION}

The edge effect in the edaphic macrofauna showed no interference in density, average richness or number of individuals in each group. It was only manifested by the presence or absence of groups with greater magnitude in the smaller fragment, which only showed the occurrence of the Blattodea and Coleoptera groups in the edge and of the Chilopoda and Formicidae groups in the transitional and inner ranges of the fragment.

The influence of the season on the edaphic macrofauna resulted in a higher density and average richness of the soil macrofauna in the dry season in the transition and interior ranges of the fragments.

\section{SUBMISSION STATUS}

Received: 2 feb., 2017

Accepted: 26 oct., 2017

\section{CORRESPONDENCE TO}

\section{Patrícia Anjos Bittencourt Barreto-Garcia}

Departamento de Engenharia Agrícola e

Solos, Universidade Estadual do Sudoeste da Bahia - UESB, Estrada do Bem Querer, Km 04, CEP 45031300, Vitória da Conquista, BA, Brasil e-mail: patriciabarreto@uesb.edu.br

\section{REFERENCES}

Abdo MTVN, Valeri SV, Ferraudo AS. Avaliação do efeito de borda da Reserva Biológica de Pindorama, SP. Revista Verde de Agroecologia e Desenvolvimento Sustentável 2015; 10(4): 1-7. 
Anderson JM, Ingram JSI. Tropical Soil Biological and Fertility: a handbook of methods. 2nd ed. Wallingford: CAB International; 1993.

Aquino AM, Silva RF, Mercante FM, Correia MEF, Guimarães MF, Lavelle P. Invertebrate soil macrofauna under different ground cover plants in the no-till system in the Cerrado. European Journal of Soil Biology 2008; 44(2): 191-197. http://dx.doi.org/10.1016/j.ejsobi.2007.05.001.

Batista MA, Timmers JF, Cunha RPP. Os Estados da Mata Atlântica: Bahia. In: Campanili M, Prochnow M. organizadores. Mata Atlântica - uma rede pela floresta. Brasília: RMA; 2006.

Bierregaard RO Jr, Lovejoy TE, Kapos V, Santos AA, Hutchings RW. The biological dynamics of tropical rainforest fragments. Bioscience 1992; 42(11): 859-866. http://dx.doi.org/10.2307/1312085.

Bolger DT, Suarez AV, Crooks KR, Morrison SA, Case TJ. Arthropods in urban habitat fragments in southern California: area, age, and edge effects. Ecological Applications 2000; 10(4): 1230-1248. http://dx.doi.org/10.1890/10510761(2000)010[1230:AIUHFI]2.0.CO;2.

Brasil. Fundação SOS Mata Atlântica. Instituto Nacional de Pesquisa espaciais. Relatório técnico. Atlas dos Remanescentes floretais da Mata Atlântica. Período 2013 - 2014. São Paulo: SOS Mata Atlântica ; 2015. p. 1-60.

Brooks TM, Mittermeier RA, Mittermeier CG, Fonseca GA, Rylands AB, Konstant WR et al. Habitat loss and extinction in the hotspots of biodiversity. Conservation Biology 2002; 16(4): 909-923. http://dx.doi.org/10.1046/ j.1523-1739.2002.00530.x.

Copatti CE, Gasparetto FM. Diversidade de insetos em diferentes tipos de borda em um fragmento de Floresta Ombrófila Mista. Revista Biociências 2013; 18(2): 32-40.

Dindal D. Soil biology guide. New York: Ed. John Wiley and Sons; 1990.

Dorval A, Peres O Fo, Marques EN. Levantamento de Scolytidae (Coleoptera) em plantações de Eucalyptus spp. em Cuiabá, estado de Mato Grosso. Ciência Florestal 2005; 14(1): 47-58. http://dx.doi.org/10.5902/198050981780.

Empresa Brasileira de Pesquisa Agropecuária - Embrapa. Centro Nacional de Pesquisa de Solos. Sistema brasileiro de classificação de solos. 2. ed. Rio de Janeiro: Embrapa; 2006.

Ferraz ACP. Efeitos de borda em florestas tropicais sobre artrópodes, com ênfase nos dípteros ciclorrafos. Oecologia Australis 2011; 15(2): 189-198. http://dx.doi.org/10.4257/ oeco.2011.1502.01.

González E, Salvo A, Valladares G. Arthropods on plants in a fragmented Neotropical dry forest: a functional analysis of area loss and edge effects. Insect Science 2015; 22(1): 129-138. http://dx.doi.org/10.1111/1744-7917.12107. PMid:24446307.

Haskell DG. Effects of forest roads on macroinvertebrate soil fauna of the southern Appalachian Mountains.
Conservation Biology 2000; 14(1): 57-63. http://dx.doi. org/10.1046/j.1523-1739.2000.99232.x.

Jouquet P, Traoré S, Choosai C, Hartmann C, Bignell D. Influence of termites on ecosystem functioning: ecosystem services provided by termites. European Journal of Soil Biology 2011; 47(4): 215-222. http://dx.doi.org/10.1016/j. ejsobi.2011.05.005.

Laurance WF, Vasconcelos HL. Conseqüências ecológicas da fragmentação florestal na Amazônia. Oecologia Australis 2009; 13(3): 434-451.

Lavelle P, Blanchart E, Martin A, Spain AV, Martin S. Impact of soil fauna on the properties of soils in the humid trofics. Madison: SSSA; 1992. (Especial publication, 29).

Lavelle P. Diversity of soil fauna and ecosystem function. Biology International 1996; 33: 3-16.

Lima-Ribeiro MS. Efeitos de borda sobre a vegetação e estruturação populacional em fragmentos de Cerradão no Sudoeste Goiano, Brasil. Acta Botanica Brasílica 2008; 22(2): 535-545. http://dx.doi.org/10.1590/S010233062008000200020 .

Lindenmayer DB, Hobbs RJ, Montague-Drake R, Alexandra J, Bennett A, Burgman $\mathrm{M}$ et al. A checklist for ecological management of landscapes for conservation. Ecology Letters 2008; 11(1): 78-91. PMid:17927771.

Murcia C. Edge effects in fragmented forests: implications for conservation. Trends in Ecology \& Evolution 1995; 10(2): 58-62. http://dx.doi.org/10.1016/S0169-5347(00)88977-6. PMid:21236953.

Pinheiro ER, Duarte LDS, Diehl E, Hartz SM. Edge effects on epigeic ant assemblages in a grassland-forest mosaic in southern Brazil. Acta Oecologica 2010; 36(4): 365-371. http://dx.doi.org/10.1016/j.actao.2010.03.004.

Primack RB, Rodrigues E. Biologia da conservação. Londrina: Viva; 2001.

Rantalainen ML, Kontiola L, Haimi J, Fritze H, Setälä H. Influence of resource quality on the composition of soil decomposer community in fragmented and continuous habitat. Soil Biology \& Biochemistry 2004; 36(12): 1983 1996. http://dx.doi.org/10.1016/j.soilbio.2004.05.017.

Ribeiro TC. Diversidade de formigas (Hymenoptera: Formicidae) de fragmentos florestais em Santa Maria, Rio Grande do Sul, Brasil [dissertação]. Santa Maria: Universidade Federal de Santa Maria; 2011.

Riutta T, Clack H, Crockatt M, Slade EM. Landscape-scale implications of the edge effect on soil fauna activity in a temperate forest. Ecosystems 2016; 19(3): 534-544. http:// dx.doi.org/10.1007/s10021-015-9939-9.

Riutta T, Slade EM, Bebber DP, Taylor ME, Malhi Y, Riordan $P$ et al. Experimental evidence for the interacting effects of forest edge, moisture and soil macrofauna on leaf litter decomposition. Soil Biology \& Biochemistry 2012; 49: 124-131. http://dx.doi.org/10.1016/j.soilbio.2012.02.028. 
Scariot A, Freitas SR, Mariano E No, Nascimento MT, Oliveira LC, Sanaiotti T et al. Vegetação e flora. In: Rambaldi DM, Oliveira DAS, organizadores. Fragmentação de Ecossistemas: causas, efeitos sobre a biodiversidade e recomendações de políticas públicas. Brasília: MMA/SBF; 2003.

Simpson JE, Slade E, Riutta T, Taylor ME. Factors affecting soil fauna feeding activity in a fragmented lowland temperate deciduous woodland. PLoS One 2012; 7(1): e29616. http://dx.doi.org/10.1371/journal.pone.0029616. PMid:22235311.

Silva RD, Aquino AD, Mercante FM, Guimarães MDF. Macrofauna invertebrada do solo sob diferentes sistemas de produção em Latossolo da Região do Cerrado. Pesquisa Agropecuária Brasileira 2006; 41(4): 697-704. http://dx.doi. org/10.1590/S0100-204X2006000400022.

Silva WG, Metzger JP, Simões S, Simonetti C. Relief influence on the spatial distribution of the Atlantic Forest cover on the Ibiúna Plateau, SP. Brazilian Journal of Biology = Revista Brasileira de Biologia 2007; 67(3): 403-411. http://dx.doi.org/10.1590/S1519-69842007000300004. PMid:18094822.

Sousa GTO, Azevedo GB, Barreto PAB, Júnior VC. Relações hipsométricas para Eucalyptus urophylla conduzidos sob regime de alto fuste e talhadia no Sudoeste da Bahia. Scientia Plena. São Cristovão 2013; 9(4): 1-7.
Tagliaferre C, Costa Santos L, Santos IJ No, Santos TJ, Rocha FA, Guimarães DU. Estimativa da evapotranspiração de referência com uso do irrigâmetro em Vitória da Conquista/BA. Irriga 2012; 17(1): 28-38. http://dx.doi. org/10.15809/irriga.2012v17n1p28.

Teixeira AFR, Silva VM, Sá Mendonça E. Fauna edáfica em sistemas arborizados de café conilon em solo de tabuleiros costeiros. Coffee Science 2014; 9(3): 385-393.

Uhlig VM. Caracterização da mesofauna edáfica em áreas de regeneração natural da floresta ombrófila densa submontanha, no município de Antonina, Paraná [dissertação]. Paraná: Universidade Federal do Paraná; 2005.

Vital ART, Guerrini IA, Franken WK, Fonseca RCB. Produção de serapilheira e ciclagem de nutrientes de uma Floresta Estacional Semidecidual em zona ripária. Revista Árvore 2004; 28(6): 793-800. http://dx.doi.org/10.1590/ S0100-67622004000600004.

Vidal MM, Pivello VR, Meirelles ST, Metzger JP. Produção de serapilheira em floresta Atlântica secundária numa paisagem fragmentada (Ibiúna, SP): importância da borda e tamanho dos fragmentos. Revista Brasileira de Botanica. Brazilian Journal of Botany 2007; 30(3): 521-532. http:// dx.doi.org/10.1590/S0100-84042007000300016.

Wirth R, Meyer ST, Leal IR, Tabarelli M. Plant herbivore interactions at the forest edge. In: Lüttge U, Beyschlag W, Murata J. Progress in botany; Berlin: Springer; 2008. p. 423-448. http://dx.doi.org/10.1007/978-3-540-72954-9_17. 